\title{
Signifying Islamic Psychology as a Paradigm: A Decolonial Move
}

\author{
Mohamed Seedat]
}

Institute for Social and Health Sciences, University of South Africa, Johannesburg, South Africa

\begin{abstract}
Recognizing the fluidity around the definitions and boundaries of Islamic psychology (IP), I propose that the assumption of decolonial thought may help IP reimagine its vision, orientation, and directions. Distinguished by three fundamentals - epistemic freedom, liberation, and humanization - paradigmatic IP may harvest psycho-spiritual, cognitive, and affective resources as well as methodological, ethical, and metaphysical substance through the creation of an archive of Islamic humanism to speak back to all areas of psychology and cognate disciplines focused on human behavior. The espousal of decolonial thought locates IP within larger bodies of solidarity and decolonizing scholarship committed to pluriversal and transformatory enactments of knowledge.
\end{abstract}

Keywords: Islam, (de)coloniality, freedom, liberation, humanization

As conceptual intervention, I propose that decolonial thought offers Islamic psychology (IP) meta-analytical resources to reconnect with its formative decolonial impulse, elaborate on its founding onto-epistemological claims and primary rootedness in the Islamic canon (the Qur'an - Islam's holy scriptures - and Prophet Muhammed's (PBUH) behavioral choices and teachings), and engage with bodies of emancipatory scholarship in support of its development. The assumption of decolonial thought places IP into conversations with "epistemologies of the South," referring to a non-geographical South and knowledges arising from intellectual and social struggles, appearing in both the geographical North and geographical South, against colonialism, transnational capitalism, and patriarchy (de Sousa Santos, 2018). This article, framed by decolonial thought, aims to contribute to the scholarship that seeks to define and authorize IP as a salient body of knowledge concerned with human behavior (Kaplick \& Skinner, 2017; Sahin, 2013; York Al-Karam, 2018a). For purposes of the argument decoloniality as praxes refers to ways of reasoning, deliberating, understanding, and doing that aspires toward pluriversal and inclusive socio-political and economic formations and humanizing knowledge practices and modes of being (Grosfoguel, 2012; Ndlovu-Gatsheni, 2013).

\section{Islam and Psychology: A Heterogenous Trajectory}

The contemporary turn to Islam and psychology, attributed to Badri (1979) who raised incompatibilities between
Islamic thought and Western psychology's ontoepistemological underpinnings, occurred against the backdrop of debates in global academia about the social and universal relevance of psychology and the emergence of the Islamization of Knowledge (IOK) movement, partially framed as Islamic "solutions" for the challenges faced by Muslims and humanity at large. Aligned to IOK the turn to Islam and psychology gained impetus through the establishment of Islamic universities in several Muslim countries that attracted a cohort of scholars including Badri who joined the department of psychology at the International Islamic University of Malaysia (IIUM) in 1992 and introduced the first undergraduate course on Islam and psychology there (Haque \& Masuan, 2002; Long, 2014).

Over a span of four decades there has been a proliferation of literature and range of organizational developments (Kaplick \& Skinner, 2017; York Al-Karam, 2018a), indicating that the trajectory of Islam and psychology is complex and heterogenous and perhaps in many respects divergent from its formative decolonial impulse. Kaplick and Skinner (2017) situate IP as one part of an Islam and psychology movement, constituted mainly by Muslim mental health practitioners and psychotherapists, educated in mainstream psychiatry and clinical psychology, as well as a range of associations located in various parts of the world. The movement, as shaped by the philosophical thought, interests, and training backgrounds of its membership, is marked by three broad approaches: the filter approach, the comparison approach, and the IP approach. These approaches are inspired by Islamic thought to varying 
degrees and may not necessarily be mutually exclusive. The filter approach aims to offer an Islamic perspective on Western psychological concepts and discerns universals within Western psychological theories that are compatible with Islamic thought; the comparison approach identifies convergences between Western psychological concepts and their assumed matches in Islamic sources; the IP approach mobilizes the Islamic canon as primary sources, and the works of classical Muslim scholars as secondary sources for its conceptualization of psychology and is focused explicitly on questioning the assumptions and uncritical universalization of Western psychological theories. Both the comparison approach, attempting to demonstrate convergences, and the filter approach, aspiring to incorporate "indigenous" Islamic psychological practices into contemporary psychology, seem to be referenced primarily against Western psychological theory and thought. Whether and how knowledge from subaltern cultures may be transposed to dominant ones is highly contested and attempts to indigenize psychology from within are critiqued for adopting problematic positivist notions of knowledge production (Long, 2014; Sayyid, 2006).

Haque, Khan, Keshavarzi, and Rothman's (2016) analysis of published studies (2006-2015), points to the differing and overlapping influences of these approaches on the Islam and psychology literature. The comparison and filter approaches are most pronounced in studies emphasizing: frameworks relevant for the development of Islamically integrated psychotherapeutic and mental health interventions and classical manifestations of Islamic psychotherapeutic practices including spiritual practices of tassawuf (Keshavarzi \& Haque, 2013; York Al-Karam, 2018b); and assessment instruments that are culturally appropriate for Muslims (Hodge \& Nadir, 2008; Thomas \& Ashraf, 2011). The Islamic approach is noticeable in work high-lighting contributions of classical Muslim scholars who, predating the emergence and formalization of psychology in the West, theorized psychology, psychiatry, human nature and personality development (Haque \& Mohamed, 2009; Keshavarzi \& Haque, 2013; Mohamed, 1995, 1996), under the broad rubric of Illm-al Nafsiat self-knowledge (Haque, 2004), and in elucidations on philosophy (falsafa), medicine (tibb/hikma), and spirituality and self-reformation (tasawwuf) (Awaad, 2018). Studies that assume the IP approach-consistent with the formative decolonial impulse also tend to critique Western psychology's materialist conceptions of human nature that ignores the idea of the soul, the metaphysical dimensions of human life (Badri, 1979; Khan, 2015).

Notwithstanding Islam and psychology's formative decolonial impulse, the salience of specific subject area accents, the criticisms of Western psychology's ethnocentric and secular biases and the theoretical work attempting epistemic correction there are a number of problematic issues that merit deliberation here (Haque et al., 2016; Kaplick \& Skinner, 2017; York Al-Karam, 2018a).

York Al-Karam (2018a), noting the absence of an explicit definition of IP and the multiple intellectual traditions that shapes the work of IP, suggests that the Multilevel Interdisciplinary Paradigm (MIP) - located in the province of psychology of religion and spirituality - may offer a conceptual structure and methodology for defining the field of IP and its interdisciplinary orientation. Effecting the conceptual and methodological logic of MIP, York Al-Karam (2018a) defines IP as "an interdisciplinary science where psychology subdisciplines and/or related disciplines engage scientifically about a particular topic and at a particular level with various Islamic sects, sources, sciences, and/or schools of thought using a variety of methodological tools" (pp. 101-102).

York Al-Karam (2018b) also presents what appears to be a widely held view that Muslim Mental Health (MMH), concerned mainly with the mental health needs of Muslims living in the West, is distinct from IP. While context sensitive approaches to $\mathrm{MMH}$ correctly brings attention to substance abuse and violence as well as the influences of war, migration, and Islamophobia on mental health, York Al-Karam (2018b) reasons that this very focus renders the area of MMH a distinct field separate from IP. While $\mathrm{MMH}$ is described as complementary to IP and as a field from which Islamic Integrated Psychotherapy (IIP) developed, its organizational pathways and professionalization trajectories are held as separate from that of IP (Basit \& Hamid, 2006).

In some respect York Al-Karam's (2018a) definition resonates with Kaplick and Skinner (2017) who propose that IP is "the interdisciplinary field that explores human nature in relation to Islamic sources and which uses this knowledge to bring human beings into their best possible state, physically, spiritually, cognitively, and emotionally" (2017, p. 199). In contrast Sahin (2013), privileging science contends that IP should not locate its onto-epistemic foundations in the Islamic canon; instead IP should be positioned as a sub-discipline of psychology of religion and employ contemporary scientific methodologies to understand the behaviors and the associated cultural dynamics of individuals who live within Islamic cultural environments. However, there is an argument that such a definition refers to Muslim psychology and not IP in that it disregards the Islamic canon as a source of knowledge (Rothman, 2018).

These definitions and the related elaborations move between referring to IP as an interdisciplinary science, distinctive field, a specialized APA accredited professional teaching program and in the case of Sahin (2013) perhaps 
as a psychology of religion. Thus, there seems to be a certain level of slippage, ambiguity, and contradiction in the descriptions and delineations of IP. The slippages and tensions are symptomatic of the complications integral to decolonizing endeavors to de-link from the problematic universalizing and homogenizing drives of hegemonic modes of knowledge (de Sousa Santos, 2018). Definitional uncertainty, analytical murkiness and theoretical incoherence as indicated by several authors (Kaplick \& Skinner, 2017, York Al-Karam, 2018a), may be compounded by a "theocentric individualism", asocial enunciations of psychology (Long, 2014, p. 16), and the over-determining influences of the Islam and psychology movement, which despite the variation in approaches seems to be concentrated primarily on incorporating Islamic knowledge traditions and values into the development and provision of Islamically integrated individualized psychotherapy (e.g., York Al-Karam, 2018b), and professionalizing IP as a distinct discipline and teaching program within the purview of mainstream psychology (Pavlova, Bariyeva, \& Bairova, 2018). The tendency to regard Islamic integrated psychotherapy as synonymous with IP may well restrict the possible evolution of IP as a paradigm which, consistent with its formative decolonial impulse, may speak back to all areas of psychology and cognate scholarship.

Courses and degree programs, framed by emerging standards of practice and emblematic of IP, offering students and practitioners training relevant to the religious and cultural values of Muslims, have been introduced through various institutions in Europe, USA, and Asia. Despite the merits of niche professional training programs (Kaplick \& Skinner, 2017; York Al-Karam, 2018b), that they may attract Muslim students mainly (and in the case of Muslim countries Shariah students mostly) raises the risks of effecting intellectual isolationism, limiting cross-disciplinary and multi-faith dialogs, and entrenching Muslims as the "Other" especially where they constitute a numerical minority. In addition, seeking accreditation from North-centric establishments entails submission to problematic regimes of academia standards, matrices, notions of science, and constructions of intellectual labour that may restrict how IP programs and associated curricula are defined and delivered, in tertiary institutions that have assumed the logic of corporatization and marketization (Long, 2014).

Most of these definitions reviewed above also position the Islamic canon - in its multiplicity - as the epistemic and pedagogical foundation for IP. Yet in their respective assumptions of scientism and empirical methodology and the recognition that neither Islam nor psychology are monolithic (York Al-Karam, 2018a), there appears to be inadequate engagement with the knowledge-power nexus and with science as a culturally and ideologically constituted mode of knowledge making (Foucault, 1977; Gordon,
1985; Shweder, 1990). Despite its foundational decolonial intentions, literature on Islam and psychology does not engage explicitly with the lurking influences of coloniality of power, knowledge, and being on the formation of hegemonic and counter-hegemonic psychologies (Seedat, 1997).

\section{(De)Coloniality and Seminal Concepts}

Coloniality signifies enduring configurations of power, knowledge, and being as both continuances and aftermaths of colonialism, in the contemporary global order marked by racism, patriarchy, and advanced transnational capitalism. Despite the dismantling of direct colonial rule and the cessation of militarized land occupations, Eurocentric domination continues to manifest in people's everyday modes of thinking, interpersonal interactions, individual and communal identities, and affective repertoires; transcending time, space, and geography (Maldonado-Torres, 2007; Ndlovu-Gatsheni, 2013).

\section{Coloniality of Power}

As an embodiment of the colonial matrix of power, the Euro-American founded secular modernist global order is constructed as the quintessential enactment of democracy, human rights, inter-subjective relations, and citizensubjects. In contrast other-than-Western people, their knowledge systems, governance formations, and modes of being are manufactured as wanting and/or incompatible with Western values and sensibilities. The "Other" is located outside of the West, a hegemonic power and knowledge structure and the supposed idealized singular modernity (Grosfoguel, 2013; Mignolo, 2007). Here "West" is to be comprehended as more than a cultural or geographical location.

Through the ascendency of secularism as an epistemological structure, the religions of the "Other," in particular that of Muslims - referenced against "Islamic" terrorism, fundamentalism, and violence in the Middle East - locates Islam as a religious structure outside of the West (Bracke \& Fadil, 2008; Mazrui, 2005; Mudimbe, 1988). Debates about Islam's compatibility with secular modernity subtly and explicitly refute Islam's relational claims to modernity and possible generative contributions to society and human development. Such discursive debates craft essentialist and monolithic understandings of Islam and so reproduce Huntington's (1996) problematic clash of civilizations thesis that disguise the influences of the coloniality of power and fail to consider the multiple trajectories of modernity (Afsaruddin, 2015; Mamdani, 2004; Massoud, 2019; Said, 1977).

In Muslim lands while the end of direct colonial rule heralded the attainment of some form of political 
independence, the ruling elites adopted macro-structural arrangements that represent a continuation of exclusionary colonial configurations of power. The Muslim ruling elites selected to maintain the colonial justice system, restricted Islamic governance frameworks to matters of family life, inheritance, and marriage and rejected calls for an inclusive legal system reflective of Islamic values that would assure people the right to follow their faiths unreservedly, regardless of religion, culture, and origin. The political elite appeased the Western powers that insisted on Western secularism as the ideal. Yet religious values and beliefs have been integrated into the constitutions of many Latin American countries where Catholicism, as introduced by Spanish colonialists, underscores laws limiting among other issues abortion and divorce. In the United States of America (USA) lawmakers routinely mobilize Christianity and Christian values in support or rejection of specific laws and the apartheid state of Israel has blended Jewish law and English common law in its legal structures (Massoud, 2019).

Contrasting the binary logic underlying discourses of a singular modernity, Eisenstadt's (2000) concept of 'multiple modernities' signals plural enactments of modernity across diverse environments and situations. Afsaruddin (2015) illustrates how Muslims have endeavored to engage Western form(s) of secularized modernity and in the dialectical process produced Islamic "modernism(s)." Each form of modernity demands specific psychologies and subjectivities. Hegemonic Euro-American modernity, reliant on dehumanizing ways of organizing humanity and premised on the paradigm of war, demands and shapes subjectivities, personhood, and inter-subjective relations through racist, capitalist, and patriarchal structures (de Sousa Santos, 2018), and is predicated on a ruling psychology that consents to extractive relationships with nature, people, and knowledge systems, and justifies consumerism, selfaggrandizement, and unbridled accumulation (Seedat, 2018; Seedat, \& Suffla, 2017).

\section{Coloniality of Knowledge}

Through the multiple processes and apparatuses integral to the colonization of knowledge including Occidentalism, the West is presumed to be the epistemic Mecca for global knowledge production and judgments about the world's people (Grosfoguel, 2012; Ndlovu-Gatsheni, 2013). While assuming the epistemic privilege to produce knowledge beyond temporal, geographical, and cultural boundaries, the Orientalization of Islam - indicative of epistemic racism provides the pseudo-intellectual basis for hegemonic Western academe to ignore, marginalize, silence, and demonize the critical knowledge contributions of classical and contemporary Muslim thinkers. Epistemic racism reduces other-than-Western cosmologies and epistemologies to the status of religion, folklore, and myth (Grosfoguel, 2012). Contemporary Islamophobia, a racist and ideologized knowledge arrangement (Sheehi, 2011), and an on-going manifestation of Orientalism (Grosfoguel, 2012), locates Islamic knowledge making and systems on the periphery and as incomprehensible to Western thought. Orientalism, traced back to the early nineteenth century, concerned with the study of diverse Oriental traditions and cultures produced problematic discourses on the people of the East, the "Orient." Terms such as "Orient" and "Occident" and "East" and "West" constituting epistemological formations were inherent to the dichotomizing colonial knowledge apparatuses (Said, 1977).

Though knowledge communities within psychology have become diverse and are interlinked to different cultural zones most of the intellectual investments in mainstream psychology continue to focus on the lifeworld of elite minorities located in privileged sites of the modern global order (Adams, Dobles, Gómez, Kurtiş, \& Molina, 2015). The incorporation of Muslim thought and writings into mainstream psychology and expressed as indicators of diversity and inclusiveness, is the exception rather than the norm. When Muslim intellectual works are considered they tend to be explained against the language and concepts of hegemonic psychology, reproducing problematic discourses and material practices, universalizing Euro-American thought and reducing Muslim thoughts on psychology as religious-cultural variants of dominant psychology (Abou-Hatab, 1997). Islamic ontology and epistemology in the main are received by a limited audience in Northern secularized academia. Muslim contributions are primarily regarded as posts from the periphery to the Western center in affirmation and elaboration of EuroAmerican constructions of psychology (Adams et al., 2015). Within hegemonic psychology, consideration of the religion-spirituality-psychology nexus is the exception rather than the norm; the overwhelming meta-theory in hegemonic psychology is a secular one that cannot meaningfully integrate Islamic and other religious worldviews (Long, 2014).

Notwithstanding the contributions of IP within spaces such as the American Psychological Association (APA) and the mobilization of grants and the proliferation of publications by Muslim scholars, the substantial intellectual and academic resources that Europe and the USA control produces a power imbalance; this imbalance is evidenced in one-way knowledge flows from the knowledge "Mecca" in the North to the global peripheries in the South that are often mined for data and information and used to entrench Euro-American knowledge traditions and methodologies (Featherstone \& Venn, 2006; Ndlovu-Gatsheni, 2018). Muslim scholars like the counterparts from the global South 
still have to join dominant Western based associations and networks and publish through Northern based production companies to obtain recognition and legitimation. Diversity and inclusiveness obfuscate on the insidious ways in which coloniality reinvents itself and the questions of democratizing psychology. The "commitment to diversity and inclusion, largely conceptualized and defined within the limits of North-centric scholarship, content, and process, for the most part, ignore or evade engagements with the coloniality of knowledge and power; diversity and inclusion cannot be determined by numbers and growth; diversity has to consider the epistemological foundations and continuities, and political commitments to transforming psychology across the globe" (Suffla, Personal Communication, November 19, 2019).

\section{Coloniality of Being}

Coloniality formed zones of being and non-being (Maldonado-Torres, 2007). Those positioned in the zones of non-being, the wretched of the earth (Fanon, 1963), face constant ontological skepticism. Muslims like all those located in the zone of non-being, denied ontological presence and autonomy, are controlled through colonial epistemic comprehension including persistent hostility and direct violence by the dominant systems. Perhaps most pronounced in the Global North a troubling process of "dialectical relationality" (Sheehi, 2019), operates to fabricate Muslim subjectivities as terrorizing and threatening. As a distancing and shaming process "dialectical relationality" in effect denies Muslims a sense of belonging within globalized forms of Western modernity, thereby provoking cognitive, social and affective pressure on Muslims to self-censor, de-Islamicize, and self-police (Sheehi, 2019).

Bulhan (1985) explains that ontological skepticism produces profound psycho-existential crises manifest in at least three psychological defensive responses and as is implied in Fanon's (1963, 1967) writings: compromise (capitulation), flight (repudiation) and fight (radicalization). Whereas capitulation is marked by a consumerist attitude, sense of exclusivity, and self-denigration, repudiation is typified by a conventional spirit, racialized consciousness, and heightened identity awareness; radicalization is characterized by a communalist outlook, class perspicacity, and fears of cooption by the dominant system. Capitulation founded on unquestioning identification with the dominant entails full assimilation with the hegemonic culture and values and rejection of the dominated cultures. Internalized oppression as capitulation is revealed partly in self-hate, low selfesteem, rejection of "indigenous" practices and values and an idealistic adoption of dominant modes of being. Repudiation is manifest in reactive rejection of the colonizing culture and a romanticized un-reflexive adoption of the 'indigenous' culture. Radicalization attempts synthesizing elements of the dominant and dominated cultures as a form of radical transformation. Sadek (2017), assuming a critical psychoanalytical reading of identity formation and in resonance with Bulhanian thought (1985), explains that Muslims responding to the shame and guilt arising from experiences of Islamophobia may adopt multiple psychological mechanisms that may result in premature identity foreclosure; while some Muslims particularly youth - tending toward capitulation - may de-link from Islam as culture and religion, others as a form of repudiation may romanticize Islamic cultures and heritage. Islam as culture and religion is invoked in essentialist and static terms. Muslim communities as a collective social defense may also deny within-group dissent; such denial may be mobilized to inscribe intra-group solidarity or underemphasize differences with the mainstream culture as part of an accommodationist impulse that may submit to dominant scripts of acceptable Islam and Muslim modes of being (Bashara, 2019; Mamdani, 2004). Such intrapsychic and social responses, underscored by a profound sense of alienation, undermine generative individual and collective agency and creative enactments of Muslim subjectivities (Sadek, 2017).

\section{Islamic Psychology: The Paradigm and Fundamentals}

I now proceed to the central argument: the assumption of decolonial thought, may enable IP to signify itself a paradigm marked by three fundamentals: epistemic freedom, liberation, and humanization.

Epistemic freedom constitutive of cognitive justice (de Sousa Santos, 2018), is the recognition of multiple ways of knowing and making sense of reality, asserting plural knowledge systems, and resisting the over-representation of Euro-American thought. Epistemic freedom "is fundamentally about the right to think, theorize, interpret the world, develop own methodologies, and write from where one is located unencumbered by Eurocentrism" (NdlovuGatsheni, 2018, p. 3). For IP epistemic freedom may be articulated as the sovereign right to assume an explicit rootedness in the Islamic canon and multiple systems of Islamicate knowledge as well as resonant bodies of thought representing epistemologies of the South. Holding tawhid as the central defining force of knowledge making, the Islamic canon in its broadest sense is the primary and foundational source from which the paradigm may derive its metaphysical, material and ethical substance, intervention practices, and pedagogical and analytical tools. Whereas Islamic knowledge, manifest in diverse classical Islamic 
scholarship, systematizes its production of knowledge according to disciplines like usul al-fiqh (jurisprudence), falsafa (philosophy), and tafsir (hermeneutics), the contemporary scholarship inclusive of Islamicate knowledge approaches the Islamic canon as a methodological, analytical, and epistemological fount. Islamicate knowledge refers to all scholarly work located within socio-political arrangements shaped by the mark and/or substance of Islam (Sayyid, 2006).

Epistemic freedom may be claimed through the creation of an archive of Islamic humanism, one critical platform from which to derive the material, metaphysical, ethical, psychological, and intellectual resources for IP to thrive as a paradigm. Epistemologies of the South that may resonate with the Islamic worldview (and its onto-epistemological claims) and classical and contemporary Muslim and Islamic scholarship as well as Islamicate bodies of knowledge would be of relevance for the construction of this archive of humanism. The archive may consider including works undertaken in the fields of Islamic Studies, Critical Muslims Studies, Religion and psychology, and other literatures that assume psychological perspectives to the study of Islam and Muslims' everyday lived realities across multiple contexts (Baderoon, 2014; Haeri, 1991; Mamdani, 2004; Sayyid, 2014). The practice of drawing on multiple bodies of knowledge places IP in conversation with counterhegemonic manifestations of psychology and raises the possibility of intellectual exchanges between scholars of world religions around conceptualizations of human nature and a range of psychosocial phenomena. The archive could thus offer decolonizing faith-based alternatives to secular psychology (Rowatt, 2013).

The tradition of inter-disciplinary knowledge production was supported by many Muslim scholars including among others Ibn Rushd who considered the generative prospects of connecting wisdom and Divine law, Ibn Taymiyyah who perceived synergies between comprehension of canonical texts and human reasoning and al-Qushayri who linked the Sufi way of life (al-Tariqah) and al-haqiqah - truths revealed in the Quran (Malkawi, 2014). Kaplick, Chaudhary, Hasan, Yusuf, and Keshavarzi (2019) in their methodology propose that convergences between different bodies of knowledge may be delimited by explaining shared theory and associated phenomena; merging methods from multiple disciplines and re-comprehending knowledge from the different disciplines without imposing consistency in the interpretations. Irrespective of the methodology that may be used to elucidate inter-disciplinary thought the development of a distinct Islamicate epistemology - by way of the archive - is more than just a recovery of pure Islam or a retreat to the orthodox knowledge-power complex; it is "the articulation of the post-Western" knowledge formation (Sayyid, 2006, p. 178).
Haque (2004) alluding to the concept of an archive suggests that the contents include contemporary and classical works translated into English from Arabic, Persian, Urdu, Turkish, and French dealing with subjects relevant to Islam and psychology. Haque's (2004) proposal, seemingly English-centric yet perhaps implicitly mindful of the lingering effects of linguicide-the eradication and peripheralization of colonized people's languages - does raise the import of including other-than-English works in the archive. The creation of a linguistically inclusive archive is part of the process of resisting the over-representation of Euroamerican thought conveyed primarily in English and de-centring the West as the epistemic Mecca (Ngugi wa Thiong'o, 1986).

The archive as an epistemic intervention may signal an explicit goal - on the part of paradigmatic IP - to interrupt the dominance of the Western canon, animate marginalized Islamic knowledges elucidating on the human condition, and situate Muslim intellectuals as generative epistemic and social change agents contributing to extending the geography of knowledge production beyond the global North.

The second fundamental liberation focuses on comprehending the intersections between power, structure and the formation of subjects and subjectivities as well as the manner by which the assumption of nation states, capitalist modes of production, and patriarchal formations may have dislocated Muslims from complex life worlds, heritage, multiple social and affective relations, nature, and the Divine (Alam, 2014). Such a comprehension of liberation resonates with Huxtable Mohr (2019), who invoking the concept of Tawhid and several Islamic principles, suggests that IP as a liberatory practice broadens its current scope and concentrates on social, gender, and environmental justice and imperial and state violence.

The social structure-subjectivities' dynamic may vary according to the cultural, socio-economic, and political arrangements under which Muslims live and enact Islam. Sayyid (2014) identifies four spaces in which Muslims enact Islam:

- Countries in which Muslims are the socio-cultural majority and where Islam may have some constitutional recognition albeit limited to matters of family law, marriage, and inheritance;

- Countries in which Muslims are the minority and peripheral to the dominant discourse and national priorities;

- Countries of the geographical West where Muslims are identified mainly as immigrants, as the "Other" in relation to the dominant culture and political formation;

- Countries where Muslim populations are small and negligible. 
In most Muslim majority countries alongside the symbols of Western modernity, manifestations of global consumerism and material excess and in spite of the political and economic formations that assume hegemonic notions of development and progress, Islamic religious and cultural values are present in people's everyday language and communication practices, social interactions, and milestone events. Everyday life is saturated in religious values, iconography and symbols resisting the material-spiritual binary; "the sacred is in proximity" (Ramadan, 2009, p. 225). The amplified five daily calls to prayer and melodious recitals of Quranic passages and prayers in public spaces may act to induce affective and cognitive attachments to Islamic values, effecting an awareness of a Transcendent God who prevails over all matters and inspires all knowledge both religious and secular (Ramadan, 2009). However, the affective-cognitive attachments to Islamic values, constituting a collective psychospiritual formation and orientation to everyday life, remains at odds and perhaps in conflict with globalized secularized modernity, hegemonic discourses on the "good and bad Muslim" (Mamdani, 2004), the pressures to assume normative secularized and Euroamericanized subjectivities.

In minority contexts Muslim subjectivities encounter the menacing forces of de-Islamization overtly and constantly and are manifest as direct, epistemic, symbolic, or structural violence (see Suffla, Malherbe, \& Seedat, in press). Direct violence, includes the genocidal extermination and/or violent displacement of Muslim populations, as is the case in contemporary Myanmar and India. Epistemic violence is the refusal to recognize Muslims as knowledge and meaning making agents and as politico-cultural subjects. Symbolic violence, masking the power relations, is the performance of power naturalizing and justifying the imposition of hegemonic representations. Epistemic and symbolic violence is perhaps most manifest in contexts where Muslims are the minority such as in India, Europe, and the USA where they tend to be typified as unwelcomed migrants; the unfathomable and/or dangerous "Other." The current Chinese government's de-Islamization program in the north-west region of the country - a materialization of epistemic and symbolic violence - is meant to eliminate awareness and memories of Muslim identity, history, and legacy (Ibrahim, 2019). The separation of children from their families and the secularization drive is a continuation of de-Islamization programs undertaken by communist regimes. Epistemic and symbolic violence, performed to erase Muslim identity, historicity and heritage and remove overt expressions of Muslim subjectivities from public spaces, produce wide ranging consequences, impacting on Muslims' psychological well-being and sense of security and belonging (Sayyid, 2014).
As liberatory praxes in minority contexts IP may focus on understanding and transforming the institutional arrangements through which direct, epistemic, and symbolic violence are performed and often manifest in Islamaphobia. In Muslim majority countries liberation may mean discerning how, despite the saturation of everyday life in Islamic cultural values, dominant socio-political arrangements, discourses, and public architecture are marshalled to entrench secular and exclusionary state formations, militarism, cultures of impunity, fabricate war criminals as heroes and silence victim-centered accounts of justice, reconciliation, and reconstruction (Joffre-Eichhorn, 2019). The discordance between the Islamic religious-spiritual ethos manifest in the everyday day material lives and psychological formations of the population and the exclusionary state structures that represent continuations of colonialism and cultures of war hold major psychological gravity for Muslim populations.

As a continuous link to Tawhid-a consciousness of Divine injunctions (Ramadan, 2009), IP as a paradigm may enact liberation as the heightening of critical awareness of the relationships between socio-political formations, exercise of power and the material, symbolic and psychological dimensions of everyday life and as "civic engagement" practices (Al-Banna, 2013), that catalyse psycho-social and material transformation of Muslim lives as a non-binary phenomenon. Such an approach to liberation brings IP into engagement with liberation psychology that emphasizes critical consciousness, de-ideologization of reality and the recovery of historical memory (Malherbe, 2018, 2019; Martín-Baró, 1994).

The third fundamental humanization - onto-epistemological recovery and presence - is comprehended as "obtaining dignity, power, agency, relationality and all the qualities that embody humanness" (Suffla \& Seedat, in press). Humanization as a complex process is founded on epistemic freedom - the sovereign right to make sense of the world from one's cosmological location (Ndlovu-Gatsheni, 2018); resistance to dominant material and discursive practices that inscribe hegemonic identity formations and subjectivities and perhaps most salient a striving against what Nandy (1983) calls the "intimate enemy," the internalized colonizing affective and cognitive scripts that produce psychic dissonance, self-doubt and affinities with colonial modes of being. As an intimate enemy colonialism changed the psychology of both the colonizer and colonized; colonialism fabricated social forces in colonized societies that altered their politico-cultural exigencies occasioning the profound internalization of Eurocentrism. Hence, the "West is everywhere, within the West and outside; in structures and minds" (Nandy, 1983, p. xi).

In this conception of humanization, Muslim subjectivities may be imagined beyond the signifiers of individual piety, 
inner reformation, or pristine pre-colonial Islamic identity as well as Islamophobic narratives of a "good Muslim." Humanization, materialized as psychological and material transformation may presume various hybrid configurations as alluded to by Sadek (2017) in her proposition-resonant with Bulhan's (1985) radicalization thesis-that Muslims "experiment" with multiple expressions of subjectivity through a confrontation of problematic internalized psychocognitive scripts and explicit engagement with issues of culture and theology.

Referenced against the Islam's theory of human nature (see Mohamed, 1995), humanization through enactments of hybrid subjectivities may be comprehended as the recovery of a relational ontology and as the process of striving to (re)become spiritual, ethical, epistemological, volitional, and psychology beings, breaking from the binaries and othering effected by coloniality. From this perspective, subjectivity is enculturated through its connection with the Divine as well as its relation to the self, epistemology, ethics, and the collective (Suffla \& Seedat, in press). Opposing ontological polarities that disconnect the secular from the spiritual, Islamic conceptions of human nature stresses the spiritual dimension of being (ruh-the soul); it references spirituality, the primordial capacity for pro-social thought and choices as well as the ability to intuit a connection with the Divine (fitrah), as fundamental marks of being and subjectivity. Despite debates about the anatomical location of the intellect (Dalhat, 2015), most Muslim scholars comprehend the heart as the site of knowing, intuition, and spiritual discernment; as the reception post through which to connect to the Divine and as the center of the psyche from where emotions originate to influence thoughts and cognitions of the aql (the mind).

In centering spirituality and the primordial capacity to connect to the Divine, the Islamic view of personhood and subjectivity resists the marks of coloniality of knowledge, and locates Muslims and all humans as epistemic agents and subjects who are endowed with the faculties of intuition, consciousness, and perception-located in the heart (qalb) as well as the capacities of cognition and thinking, constituting the intellect (aql). Epistemic agency is enabled by the capacities to comprehend reality, intuition, reason and make knowledge through sensory, spiritual, and intellectual processes. Even though Islamic epistemology resists the secularized tenets of dominant Western knowledge systems and positions the Islamic canon-specifically revelation - as a foundation of knowledge, it does not dismiss the functions of the brain in intellectual activities. The heart (qalb) is conceptualized as the spiritual and the consciousness center of humans as well as the intellect-the (aql) (Rothman \& Coyle, 2018). Following contemporary scientific insights some Muslim scholars posit that the heart comprises of neurons that generate the abilities of thinking, sensing, intuiting and that supports the heart to function as the site of discernment and knowing both the Divine and the material (Dalhat, 2015).

Yet epistemic agency assumes forms of dynamic struggle in that the heart (qalb) as the center of discernment and knowledge-making faces constant intrusions in the guise of narcissistic impulses arising from the lower self (nafs), approximating the Id in Freudian psychology and/or vicissitudes of material existence that may induce a state of forgetting (ghafla) God; a state that disrupts the primordial connection to the Divine and capacities for generative choices (Rothman \& Coyle, 2018). In situations of prolonged coloniality epistemic agency, in part buttressed by the primordial capacity for rectitude, may be undermined simultaneously by hegemonic narratives of subjectivity, alienating and unjust social structures, and over-identification with the "noise" effected by the internalization of dominant Eurocentric narratives and the self-absorbing tendencies of the lower self. In this reading, epistemic agency means "living with" and finding ways of transcending structural impediments as well as the on-going intrapsychic conflict between the primordial capacities for linking to the Divine and generativity, and the destructive tendencies constituted as troublesome attributes that often operate unconsciously and that are manifest in negative thoughts and feelings and comprehended as the countergenerative dimensions of being (Mohamed, 1996).

In the material realm epistemic agency may translate as enactments of ethico-political praxis, signifying resistance to dehumanizing narratives, social arrangements and othering practices; the mobilization of self-recognition, selfaffirmation and agency as crucial psycho-political resources for countering the consequences of ontological alienation and (re)forming the self as a relational process of engagement with the Divine, the other, cultural and theological legacies, language, nature, and history as well as range of communities of significance (Bulhan, 1985; MaldonadoTorres, 2007; Sadek, 2017; Suffla \& Seedat, in press).

\section{Conclusion}

The assumption of decolonial thought provides the interpretive resources for IP to move beyond its definitional troubles, expand on its current borders and foci, and signify itself as a paradigm discernible by three fundamentals: epistemic freedom, liberation, and humanization. An explicit concentration on epistemic freedom opens intellectual spaces for IP to re-connect to its foundational decolonial turn, contribute to democratizing knowledge systems, and assert Islam as a legitimate body of knowledge for making and reconstructing psychology. As part of a transnational 
decolonial activist turn IP may link with knowledges produced within multiple epistemic sites of the South, resist possible intellectual isolation and exceptionalism, and raise its relevance for pluriversal understandings of human development in a pluriversalized cultural world. The centering of liberation and humanization raises critical consciousness about the influences of exclusionary power and social formations on Muslims' psychological lives and subjectivities and apprehends the recovery and enactment of relational ontologies as inconceivable without both inner psychological reformation and ethico-political transformation, respectively (Suffla $\&$ Seedat, in press).

The focus on epistemic freedom, liberation, and humanization moves the borders of IP beyond the asocial and ahistorical concentration on individualized identity formation and exclusive intrapsychic reformation; enculturates spiritualized modes of being and encourages rethinking conceptions of human nature as well the anatomical sites and processes of consciousness, comprehension, intuition, and modes of knowledge making. As such decolonial thought may help IP to shift its locus of analysis from the purely psychological to the psycho-political and opens conceptual spaces to socialize, elaborate, and rethink thinking about human nature, $a q l$ and qalb and personality development as well as knowledge making in the context of coloniality and the contemporary crises manifest in environmental, political, and economic challenges of our time.

\section{References}

Abou-Hatab, F. A.-L. H. (1997). Psychology from Egyptian, Arab, and Islamic perspectives: Unfulfilled hopes and hopeful fulfillment. European Psychologist, 2, 356-365. https://doi.org/ 10.1027/1016-9040.2.4.356

Adams, G., Dobles, I., Gómez, L. H., Kurtiş, T., \& Molina, L. E. (2015). Decolonizing psychological science: Introduction to the special thematic section. Journal of Social and Political Psychology, 3, 213-238. https://doi.org/10.5964/jspp.v3i1.5

Afsaruddin, A. (2015). Contemporary issues in Islam. Edinburgh, UK: Edinburgh University Press.

Al-Banna, S. H. (2013). Spiritual and civic engagement - The prophetic model. Retrieved from https://www.cilecenter.org/.../ spirituality-and-civic-engagement-prophetic-model

Alam A. (Ed.). (2014). Arab spring: Reflections on political changes in the Arab world and its future. New Delhi, India: New Century Publications.

Awaad, R. (2018, October). Historical perspectives and Modern clinical Implications for the development of Islamic Psychology. Paper presented at the Conference of the International Association of Islamic Psychology, Istanbul, Turkey.

Baderoon, G. (2014). Regarding Muslims from slavery to postapartheid. Johannesburg, South Africa: Wits University Press.

Badri, M. (1979). The dilemma of Muslim psychologists. London, UK: MWH London.

Bashara, R. K. (2019). Decolonial psychoanalysis. Towards critical Islamophobic studies. New York, NY: Routledge.
Basit, A., \& Hamid, H. (2006). Editors' introduction. Journal of Muslim Mental Health, 1, 1-3. https://doi.org/10.1080/ 15564900600764911

Bracke, S., \& Fadil, N. (2008). Islam and secular modernity under Western eyes: A genealogy of a constitutive relationship. European University Institute, Florence: Robert Schuman Centre for Advanced studies Mediterranean Programme. EUI working paper RSCAS 2008/05. Retrieved from https://www.tandfonline.com/ doi/ref/10.1080/00207598008246986?scroll=top

Bulhan, H. A. (1985). Frantz Fanon and the psychology of oppression. New York, NY: Plenum Publishing.

Dalhat, Y. (2015). The concept of al-AQL (reason) in Islam. International Journal of Humanities and Social Science, 5, 77-83.

de Sousa Santos, B. (2018). The end of the cognitive empire: The coming of age of epistemologies of the South. Durham, NC: Duke University Press.

Eisenstadt, S. (2000). Multiple modernities. Daedalus, 129, 1-29. Retrieved from http://www.jstor.org/stable/20027613

Fanon, F. (1963). The wretched of the Earth. New York, NY: Grove Press.

Fanon, F. (1967). Black skins, white masks. New York, NY: Grove Press.

Featherstone, M., \& Venn, C. (2006). Problematizing global knowledge and the new Encyclopaedia Project. Theory Culture \& Society, 23, 1-20.

Foucault, M. (1977). Language, counter-memory, practice: Selected essays and interviews. Ithaca, NY: Cornell University Press.

Gordon, E. W. (1985). Social science knowledge production and minority experiences. Journal of Negro Education, 54, 117-133. https://doi.org/10.2307/2294927

Grosfoguel, R. (2012). The multiple faces of Islamophobia. Islamophobia Studies Journal, 1, 9-33. https://doi.org/10.13169/ islastudj.1.1.0009

Grosfoguel, R. (2013). The structure of knowledge in Westernized universities: Epistemic racism/sexism and the four genocides/ epistemicides of the long 16th century. Human Architecture: Journal of the Sociology of Self-Knowledge, 11, 73-90.

Haeri, S. F. (1991). The journey of the self. A Sufi guide to personality. New York, NY: Harper Collins.

Haque, A. (2004). Psychology from Islamic perspective: Contributions of early Muslim scholars and challenges to contemporary Muslim psychologists. Journal of Religion \& Health, 43, 357377. https://doi.org/10.1007/s10943-004-4302-z

Haque, A., Khan, F., Keshavarzi, H., \& Rothman, A. E. (2016). Integrating Islamic traditions in modern psychology: Research trends in last ten years. Journal of Muslim Mental Health, 10, 75-100. https://doi.org/10.3998/jmmh.10381607.0010.107

Haque, A., \& Masuan, K. A. (2002). Religious psychology in Malaysia. International Journal for the Psychology of Religion, 12, 277-289. Retrieved from https://www.tandfonline.com/doi/ abs/10.1207/S15327582IJPR1204_05

Haque, A. \& Mohamed, Y. (Eds.). (2009). Psychology of personality: Islamic perspectives. Kuala Lumpur, Malaysia: Cengage Learning Asia.

Hodge, D. R., \& Nadir, A. (2008). Moving toward culturally competent practice with Muslims: Modifying cognitive therapy with Islamic tenets. Social Work, 53, 31-41. https://doi.org/ 10.1093/sw/53.1.31

Huntington, S. P. (1996). The clash of civilizations and the remaking of world order. New York, NY: Simon \& Schuster.

Huxtable Mohr, S. (2019). Liberation psychology from an Islamic perspective. Some theoretical and practical implications of psychology with a telos of justice. Journal of Religion and Society, 21, 1-22. Retrieved from http://hdl.handle.net/10504/122276

Ibrahim, A. (2019). China must answer for cultural genocide in court. Foreign policy. The Global Magazine of News and Ideas. 
December 3, 2019. Retrieved from https://foreignpolicy.com/ 2019/12/03/uighurs-xinjiang-china-cultural-genocide-internatio Joffre-Eichhorn, H. J. (2019). The Memory box-initiative: Nonextractivist research methodologies and the struggle for an architecture of remembrance in Kabul, Afghanistan. Cultural Studies, Critical Methodologies, 1-16. https://doi.org/10.1177/ 1532708619863008

Kaplick, P. M., Chaudhary, Y., Hasan, A., Yusuf, A., \& Keshavarzi, H. (2019). An interdisciplinary framework for Islamic cognitive theories. Zygon, 54, 66-86. Retrieved from https://onlinelibrary. wiley.com/doi/pdf/10.1111/zygo.12500

Kaplick, P. M., \& Skinner, R. (2017). The evolving Islam and psychology movement. European Psychologist, 22, 198-204. https://doi.org/10.1027/1016-9040/a000297

Keshavarzi, H., \& Haque, A. (2013). Outlining a psychotherapy model for enhancing Muslim mental health within an Islamic context. International Journal for the Psychology of Religion, 23, 230-249. https://doi.org/10.1080/10508619.2012.712000

Khan, R. K. A. W. (2015). An interview with Professor Malik Badri about his contributions to the Islamisation of psychology. Intellectual Discourse, 23, 159-172. Retrieved from https:// search.proquest.com/openview/6b48a802e43ee44335269e8a8 $13 \mathrm{c} 1 \mathrm{edb} / 1$ ?pq-origsite $=$ gscholar $\& \mathrm{cbl}=826340$

Long, W. (2014). Critical reflections on the Islamicisation of psychology. Revelation and Science, 4, 14-19. Retrieved from https://www.researchgate.net/publication/

Maldonado-Torres, N. (2007). On the coloniality of being: Contributions to the development of a concept. Cultural Studies, 21, 240-270. https://doi.org/10.1080/09502380601162548

Malherbe, N. (2018). Expanding conceptions of liberation: Holding Marxism with liberation psychology. Theory \& Psychology, 28, 340-357. https://doi.org/10.1177/0959354318767757

Malherbe, N. (2019). Articulating liberation psychologies of culture. Journal of Theoretical and Philosophical Psychology. Advance online publication. https://doi.org/10.1037/teo0000126

Malkawi, F. H. (2014). Epistemological Integration. Essentials of an Islamic Methodology. Washington DC: The International Institute of Islamic Thought.

Mamdani, M. (2004). Good Muslim, Bad Muslim: America, the cold war, and the roots of terror. New York, NY: Pantheon.

Martín-Baró, I. (1994). Writings for a liberation psychology. Cambridge, MA: Harvard University Press.

Massoud, M. F. (2019, April 8). Don't blame Sharia for Islamic extremism blame colonialism. Retrieved from https:// theconversation.com/dont-blame-sharia-for-islamic- extremismblame-colonialism-109918

Mazrui, A. A. (2005). The re-invention of Africa: Edward Said, V. Y. Mudimbe and beyond. Research in African Literatures, 36, 68-82. Retrieved from http://www.jstor.org/stable/3821364

Mignolo, W. (2007). Coloniality of power and de-colonial thinking. Cultural Studies, 21, 155-167. https://doi.org/10.1080/ 09502380601162498

Mohamed, Y. (1995). Fitrah and its bearing on the principles of psychology. The American Journal of Islamic Social Sciences, 12, 1-18. Retrieved from https://search.proquest.com/ openview/b9b0fd850d8f9bcc47b15dbb9eacd02b/1?pq-origsite= gscholar\&cbl=1819750

Mohamed, Y. (1996). Fitra. The Islamic concept of human nature. London, UK: Ta-Ha Publishers.

Mudimbe, V. Y. (1988). The invention of Africa: Gnosis, philosophy, and the order of knowledge. Indianapolis, IN: Indiana University Press.

Nandy, A. (1983). The intimate enemy: Loss and recovery of self under colonialism. New Delhi, India: Oxford University Press.
Ndlovu-Gatsheni, S. J. (2013). Empire, global coloniality and African subjectivity. New York, NY: Berghahn Books.

Ndlovu-Gatsheni, S. J. (2018). Epistemic freedom in Africa: Deprovincialization and decolonization. London, UK: Routledge. Ngugi wa Thiong'o. (1986). Decolonising the mind: The politics of language in African literature. London, UK: J. Currey.

Pavlova, O. S., Bariyeva, N. Yu., \& Bairova, Z. M. (2018). IP abroad minbar. Islamic Studies, 11, 850-865. https://doi.org/ 10.31162/2618-9569-2018-11-4-850-865

Ramadan, T. (2009). Islam, the West and the challenges of modernity. United Kingdom: The Islamic Foundation.

Rothman, A. (2018). An Islamic theoretical orientation to psychology. In C. Y. Al-Karam (Ed.), Islamically Integrated Psychotherapy. Uniting faith and professional practice (pp. 36-64). West Conshohocken, PA: Templeton Press.

Rothman, A., \& Coyle, A. (2018). Toward a framework for Islamic psychology and psychotherapy: An Islamic model of the soul. Journal of Religious Health, 57, 1731-1744. https://doi.org/ 10.1007/s10943-018-0651-x

Rowatt, W. C. (2013). Response to "Reflections on the Possibility of an IP" by Adam Sahin (2013) in Archive for the Psychology of Religion, 35, pp. 321-336. Archive for the Psychology of Religion, 35, 337-346. https://doi.org/10.1163/15736121-12341269

Sadek, N. (2017). Islamophobia, shame, and the collapse of Muslim identities. International Journal of Applied Psychoanalytic Studies, 14, 200-221. https://doi.org/10.1002/aps.1534

Sahin, A. (2013). Reflections on the possibility of an IP. Archive for the Psychology of Religion, 35, 321-335. https://doi.org/ 10.1163/15736121-12341270

Said, E. W. (1977). Orientalism. New York, NY: Pantheon Press.

Sayyid, S. (2006). Islam and knowledge. Theory, Culture and Society, 23, 177-179. https://doi.org/10.1177/026327640602300230

Sayyid, S. (2014). A measure of Islamophobia. Islamophobia Studies Journal, 2, 10-25. https://doi.org/10.13169/ islastudj.2.1.0010

Seedat, M. (1997). The quest for liberatory psychology. South African Journal of Psychology, 27, 261-270. https://doi.org/ $10.1177 / 008124639702700410$

Seedat, M. (2018, September 18). We must build on psychology of peace. Opinion Piece. Mail and Guardian. Retrieved from https: //mg.co.za/article/2015-09-17-we-must-build-on-psychologyof-peace

Seedat, M., \& Suffla, S. (2017). Community psychology and its (dis)contents, archival legacies and decolonization. Special Issue: Liberatory and critical voices in decolonizing community psychology. South African Journal of Psychology, 47, 421-431. https://doi.org/10.1177/0081246317741423

Sheehi, L. (2019). The Islamophobic normative unconscious: Psychoanalytic considerations. In H. S. Moffic, J. Peteet, H. Z. Hankir, \& R. Awaad (Eds.), Islamophobia and psychiatry. Recognition, prevention and treatment (pp. 157-171). Cham, Switzerland: Springer Nature Switzerland AG.

Sheehi, S. (2011). Islamophobia: The ideological campaign against Muslims. Georgia: Clarity Press.

Shweder, R. A. (1990). Cultural psychology. What is it? In J. W. Stigler, R. A. Shweder, \& G. Herdt (Eds.), Cultural Psychology. Essays on comparative human development (pp. 1-44). Cambridge, UK: Cambridge University Press.

Suffla, S., Malherbe, N., \& Seedat, M. (in press). Recovering the everyday within and for decolonial peacebuilding through politico-affective space. In S. M. Moss, Y. G. Acar, \& O. M. Ulug (Eds.), Researching peace and conflict: Field experiences and methodological reflections. Cham, Switzerland: Springer International Publishing. 
Suffla, S., \& Seedat, M. (in press). Africa's knowledge archives, Black Consciousness and reimagining community psychology. In G. Stevens \& C. Sonn (Eds.), Decoloniality, knowledge production and epistemic justice in contemporary community psychology. Cham, Switzerland: Springer International Publishing.

Thomas, J., \& Ashraf, S. (2011). Exploring the Islamic tradition for resonance and dissonance with cognitive therapy for depression. Mental Health, Religion \& Culture, 14, 183-190. https:// doi.org/10.1080/13674676.2010.517190

York Al-Karam, C. (2018a). IP: Towards a 21st century definition and conceptual framework. Journal of Islamic Ethics, 2, 7-109. https://doi.org/10.1163/24685542-12340020

York Al-Karam, C. (2018b). Islamically integrated psychotherapy. Uniting faith and professional practice. West Conshohocken, PA: Templeton Press.

\section{History}

Received August 16, 2019

Revision received February 1, 2020

Accepted March 17, 2020

Published online July 9, 2020

\section{Acknowledgments}

Special thanks to Ghouwa Ismail, Zoliswa Ntsoko and Shahnaaz Suffla for their respective intellectual, technical, and moral support.

\section{ORCID}

Mohamed Seedat

(D)https://orcid.org/0000-0001-9018-3370

\section{Mohamed Seedat}

Institute for Social and Health Sciences

University of South Africa

Box 1087, Lenasia

1821 Johannesburg

South Africa

seedama@unisa.ac.za

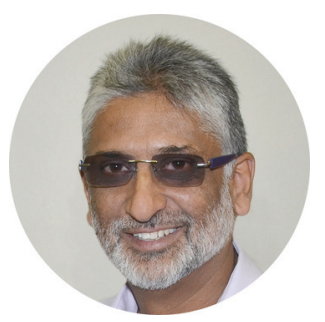

Mohamed Seedat's research is on the social anatomy of public protests, grassroots cultures of peace and safety, and the psycho-politics underlying multiple struggles for decolonized caring societies. He contributes to emancipatory community intervention practices and the transformation of exclusionary writing cultures. Mohamed Seedat also directs Unisa's Institute for Social and Health Sciences. 